\title{
固体物性解析技術 超伝導測定法
}

\author{
能登宏七* 松川倫明** 藤代博之**
}

\section{1.はじめに}

1908年にヘリウムが初めて液化されたのに引き続いて, 1911年に超伝導現象が発見された．その後，1950年代後半 に, その発現機構の解明が行われ，1960年代前半より種々 の応用の研究が芽生光始めた。発見後75周年を迎えた1986 年の時点では, $\mathrm{NbTi}_{1}, \mathrm{Nb}_{3} \mathrm{Sn}$ 超伝導線材 (極細多芯線) と超 伝導薄膜接合の研究の進歩に伴って, MRI, SQUID が実用 化され, 各種高磁界マグネット, 加速器用マグネット, 粒子 検出用マグネット，核融合用のプラズマ閉じ込め用コイル， 超伝導リニア用 MAGLEV ユイル, 電力応用に向けた研究 やジョセフソンュンピューター用素子の開発等々の開発研究 が盛んに行われていた ${ }^{(1)}$. したがって，この時点では，種々 の超伝導特性の測定法は, ほぼ確立し, 用語を初めとして, 種々の超伝導特性測定の試験・評価方法の標準化が急がれる 段階にあった…上らに思われた。

しかしながら, この1986年の後半に酸化物高温超伝導体 が発見され, その臨界温度 $T_{\mathrm{C}}$ は, 突如らなぎ登りを始め た。それ迄最高だった $23 \mathrm{~K}\left(\mathrm{Nb}_{3} \mathrm{Ge}\right)$ から，一気に液体窒素 温度 $(77 \mathrm{~K})$ を突破し, 数年のらちに $160 \mathrm{~K}$ (水銀系高圧下) の領域にまで到達している(2). 以後は，BCS 理論では到底 説明できないこれらの高温超伝導の発現機構を解明しょらと 与る研究と, これら高温超伝導材料の実用化へ向けての開発 研究に主力が注がれて来ている.これらの酸化物高温超伝導 体は，多様で特異な性質を示すため，その種々の特性の測定
法を見直さざるを得なくなった現在は，発現機構の解明，更 なる高温超伝導体の探索, および工学的実用化研究の面から も, 諸物性のデータベースの構築, 試験・評価方法の標準化 が急務となっている.

本稿では, 超伝導体特有の性質として, 臨界温度 $T_{\mathrm{C}}$, 臨 界磁界 $H_{\mathrm{C}}$, 臨界電流密度 $J_{\mathrm{C}}$ の測定法および筆者らの得意と する熱伝導率 $K(T, H)$, 熱拡散率 $D(T)$, ゼーベック係数 (熱起電力) $S(T)$ の測定法を, その対象を, 酸化物高温超伝 導材料を中心として解説することとする.な拉, 本稿中の超 伝導特有の用語の意味, 定義などについては, 簡単な説明を 入れたつもりであるが, 詳細については, 他のテキストを参 照されたい。

\section{2. 臨界温度 $\boldsymbol{T}_{\mathrm{C}}$ の測定法}

超伝導の 4 大特徵として, (1)完全導電性, (2)完全反磁 性, (3)磁束の量子化, (4)ジョセフソン効果を示すことが挙げ られる. (1)の完全導電性は, 超伝導体中で電界 $E \equiv 0$, した がって電気抵抗率 $\rho \equiv 0$ を意味する. (2)の完全反磁性は, 超 伝導体中で磁束密度 $B \equiv 0$ を意味与る。これは, マイスナー 効果とも呼ばれる. (3)の磁束の量子化は, 超伝導体中に侵入 した磁束や, 超伝導リング内にトラップされた磁束が $\phi=$ $n \phi_{0}\left(\phi_{0}=h / 2 e, n:\right.$ 正整数) の如く量子化することを意味し, (4)のジョセフソン効果は, 超伝導電子対(クーパーペア)がポ

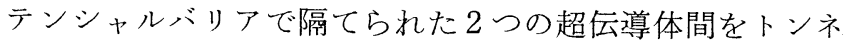
リングすること, したがって, 電気揩抗零のトンネル接合

* 岩手大学教授 ; 工学部材料物性工学科 ( 020 盛岡市上田4-3-5)

** 岩手大学助教授; 工学部材料物性工学科

Material Properties Analyzing Techniques - Methods of Superconducting Properties Measurements-; Koshichi Noto, Michiaki Matsukawa, Hiroyuki Fujishiro (Department of Materials Science and Technology, Faculty of Engineering, Iwate University, Morioka) Keywords: superconductor, measurement technique, high critical temperature, oxide superconductor, critical temperature, critical field, critical current density, thermal conductivity, thermal diffusivity, Seebeck coefficient 1996年11月14日受理 


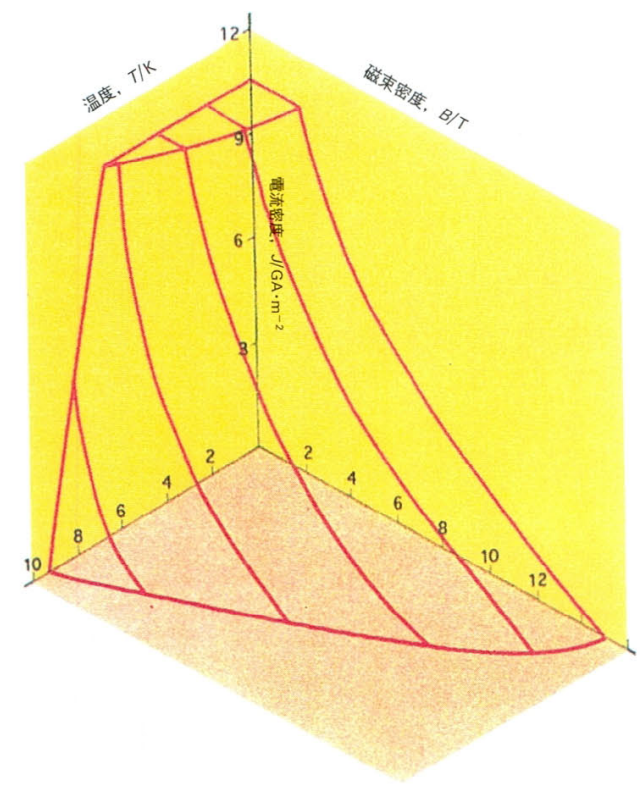

図 1 超伝導体の臨界曲面の 1 例. 本図は, NbTi の場 合である。

(これをジョセフソン接合という)が実現されることを意味す る。超伝導現象の検出には, これらの特性の計測が用いられ る。また，超伝導体は，3つの臨界值を持つ。与なわち，(a) 臨界温度 $T_{\mathrm{C}}$, (b)臨界磁界 $H_{\mathrm{C}}$, ( ) 臨界電流密度 $J_{\mathrm{C}}$ である. 温度 $T$, 磁界 $H$, 電流密度 $J$ の 3 次元空間に打いて, これ ら 3 つの臨界值に上る曲面が各超伝導体について存在し, この臨界面の下の空間(原点側)でのみ, 超伝導性が現れる. この臨界面の 1 例を図 1 亿示与.

$T_{\mathrm{C}}$ の測定としては, 電気抵抗率の温度依存性 $\rho(T)$ 測定 による方法, 交流带磁率の温度依存性 $\chi_{\mathrm{AC}}(T)$ 測定に上る方 法, 直流磁化率の温度依存性 $\chi_{\mathrm{DC}}(T)$ 測定による万法などが 主でめる。直流磁化率測定にはVSM(振動試料型磁束計)や SQUID (超伝導量子干渉磁束計)などが用いられる。 $\rho(T)$ に よる万法は，上記(1)(完全導電性)の特徵を利用するものであ り， $\chi_{\mathrm{AC}}(T)$ と $\chi_{\mathrm{DC}}(T)$ による方法は, 上記(2)(完全反磁性) の特徵を利用するものである。

従来からの金属系低温超伝導体の場合，上記の諸技術によ る $T_{\mathrm{C}}$ の測定結果は, 非常に良い精度で一致し, したがって どの方法で $T_{\mathrm{C}}$ を決定しても良く, 問題は生じなかった。 し かしながら, 酸化物高温超卮導体の場合には, 必ずしも良く 一致しないことが判明している。これは， $T_{\mathrm{C}}$ 近くでのゆら ぎ現象, 巨大磁束流 (giant flux flow), 磁束》リープ (flux creep), 弱結合 (weak link), 2 次元的異方性 (anisotropy)等 々が複雑に関与しているためと思われる。

\section{(1) 電気抵抗率法}

図 2 に転移点近傍での典型的な電気抵抗率の温度依存性を

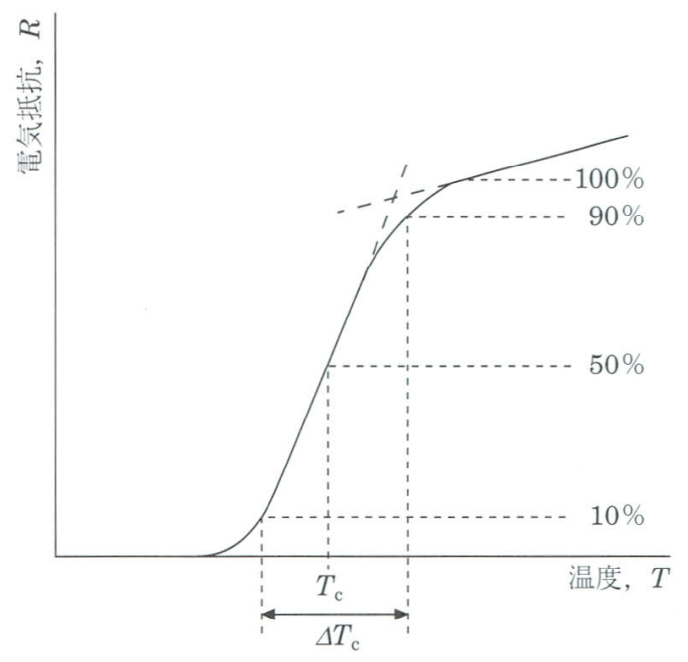

図 $2 p(T)$ の $T_{\mathrm{C}}$ 近傍での典型的振舞いの模式図.

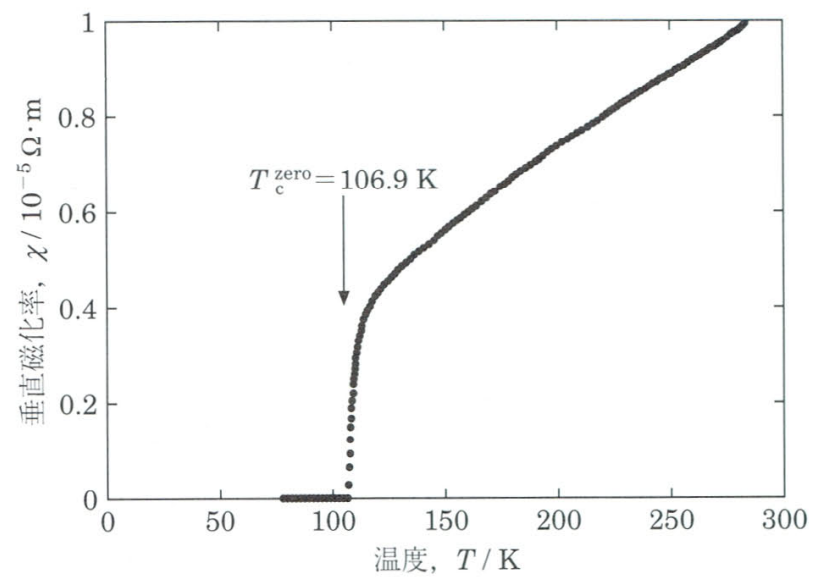

図 3 高配向 $(\mathrm{Bi}, \mathrm{Pb})_{2} \mathrm{Sr}_{2} \mathrm{Ca}_{2} \mathrm{Cu}_{3} \mathrm{O}_{x}$ バルク材における $\rho(T)$ 法での $T_{\mathrm{C}}$ 測定例.

示す．金属系低温超伝導体の場合，良く使われる表示として は, 抵抗率が転移直上の常伝導状態での值の $50 \%$ になる温 度をもって $T_{\mathrm{C}}$ としている例が多い、更に，転移のシャープ さを表示するために，転移幅 $\Delta T$ を示与場合もある.

酸化物高温超质導体の場合は, 前記の特徵を反映して, 転 移幅が広い場合が多く, 電気抵抗率が常伝導状態からの接線 より離れ始める温度をもって $T_{\mathrm{C}}^{\text {nset }}$, 電気抵抗率がゼ口にな る温度をもって T R C zero と表示することが多い。しかしなが ら， T C onset にはゆらぎの効果などが影響するし， $T_{\mathrm{C}}^{\text {zero }}$ には 巨大磁束流, 磁束》リープなどの影響で, 測定の為の通電電 流密度にも依存与る. 多くの場合, T C Cro $^{2}$ の判定基準として は， $\rho \leqq\left(10^{-7} \sim 10^{-9}\right) \Omega \cdot \mathrm{m}$ ，または電界基準として， $E \leqq 10$ $\mu \mathrm{V} / \mathrm{m}$ が用いられている。測定電流密度としては, 筆者ら は $J \leqq 10^{4} \mathrm{~A} / \mathrm{m}^{2}$ を採用している. $\rho(T)$ 測定の場合, 正しい 4 端子法で測定することが肝要であるが, 端子接続の方法と 
しては，銀ぺースト使用，Inを用いた超音波半田付け，圧 着法, 金線のスポットウェルド\&アニールなどの諸法が試 みられている。高配向 $(\mathrm{Bi}, \mathrm{Pb})_{2} \mathrm{Sr}_{2} \mathrm{Ca}_{2} \mathrm{Cu}_{3} \mathrm{O}_{x}$ での測定例を 図3に示寸.

\section{(2) 磁化率法}

磁化率法に打ける $T_{\mathrm{C}}$ の判定基準としては, 常磁性領域で の磁化率と反磁性を生じた領域での磁化率の温度依存の接線 の交点に和忷る温度をもって $T_{\mathrm{C}}$ とする場合や反磁性磁化率 が $\chi=-4 \pi \times\left(10^{-7} \sim 10^{-10}\right) \mathrm{Wb} / \mathrm{m}^{2}$ の範囲内の一定値, 例 えば $\chi=-4 \pi \times 10^{-7} \mathrm{~Wb} / \mathrm{m}^{2}$ を示した温度をるって $T_{\mathrm{C}}$ とす る場合もある。この場合も測定のための印加磁界依存性が考 えられるので, 筆者らの場合, $(1 / 4 \pi) \times 10^{4} \mathrm{~A} / \mathrm{m}(10 \mathrm{Oe})$ 以 下の磁界を印加して測定している.

\section{3. 臨界磁界測定法}

超厷導体は, その磁化過程に従って, 第 1 種超层導体 (Type I ) と第 2 種超伝導体(Type II) とに分類される. 図 4 は, 理想的な超伝導体の磁化の磁界依存性を示す。（反磁界 係数 $=0$ とする)Type I では，(a)の如く， $H_{\mathrm{C}}$ まで完全反磁 性を示し，この磁界值で常层導状態に転移する. TypeIIで は, 下部臨界磁界 $H_{\mathrm{C} 1}$ をで完全反磁性を示し, これ以上の 磁界では, 超伝導マトリックス中に量子化した磁束が侵入し た混合状態となり, 上部臨界磁界 $H_{\mathrm{C} 2}$ で常层導状態に転移 する. この場合も熱力学的臨界磁界 $H_{\mathrm{C}}$ が定義されており， 図中 (b)で, A の面積と B の面積が等しくなるような磁界の 值となっている(表面超伝導が消失する臨界磁界 $H_{\mathrm{C} 3}$ につい ては省略する). Type I では, 当然のことながら， $H_{\mathrm{C}}$ まで 電気抵抗は零であり, Type II では, 酸化物高温超卮導体が 発見される迄は， $H_{\mathrm{C} 2}$ まで電気抵抗が零と考㝋て問題は生じ なかった. したがって, これらの臨界磁界値の決定法として, Type I の $H_{\mathrm{C}}$ や Type II の $H_{\mathrm{C} 2}$ には, 磁化の磁界依存性 $M(H) や \rho(H)$ の測定が， Type II $H_{\mathrm{C}}$ には，比熱 $C$ の測 定门などが用いられて来た．金属系の低温超卮導体では，こ れらの測定結果は，抢互いに良い精度で一致していた。しか しながら, 酸化物高温超层導材料は, 一非理想的な Type II と考光られている一既に述べた磁束流, 磁束クリープや，ゆ らぎの効果が影響し, 更に不可逆効果などが複雑に絡んで, これらの臨界磁界値を正確に測定することは難しいといわざ るを得ない．理論的解明が未だ完全になされていないことが その大きな原因の 1 つである. 不可逆効果とは, 磁化の温 度依存性または磁界依存性が不可逆になる効果で, 図 5 の上 らな磁化曲線を示す. 図中の $H_{\mathrm{irr}}$ は不可逆磁界と呼ばれ, $H_{\mathrm{irr}}$ の温度依存性を示す曲線は, 不可逆曲線と呼ばれる. 現

$† C(T)$ の測定結果より, 超伝導と常伝導の自由エネルギー差を 求め, それが超伝導凝縮エネルギー: $(1 / 2) \mu_{0} H_{\mathrm{C}}^{2}$ に等しいこと から $H_{\mathrm{C}}$ を求める。
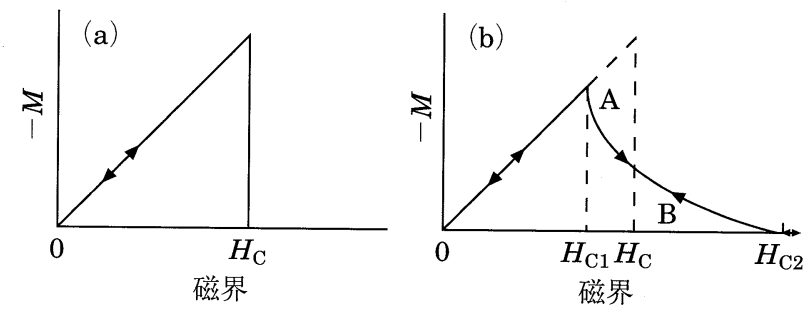

図 4 理想的超伝導体の磁化の磁界依存性.（a)は第 1 種超伝導体，（b) は第 2 種超伝導体の場合であ る.

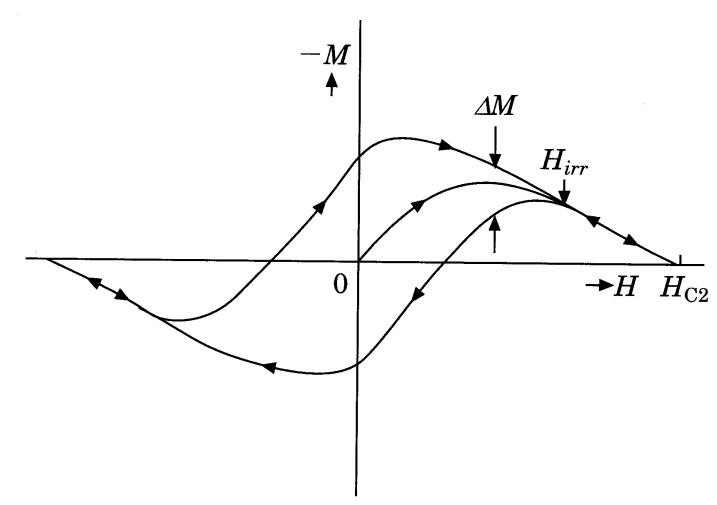

図 5 不可逆効果を示す磁化過程の模式図. $H_{\mathrm{C} 2}$ より 低い磁界值 $H_{\text {irr }}$ をで，磁化がヒステリシスを示 す. $H_{\text {irr }}$ は不可逆磁界と呼ばれる.

時点で用いられている測定法を，筆者なりにまとめて，項目 別に箇条書きする.

$H_{\mathrm{C} 1}$ ：処女状態から磁化を測定し始めて，完全反磁性の直線 から，はずれ始める磁界值

$H_{\mathrm{C} 2}$ ：常厷導状態から，磁界を下降させながら磁化を測定 し，常磁性から反磁性側に，はずれ始める磁界値．多 くの酸化物高温超伝導体では， $H_{\mathrm{C} 2}$ 值が非常に大き く, $T_{\mathrm{C}}$ の極く近傍を除いて, 正確な測定は困難であ る.

$H_{\mathrm{C}}$ : 現在の処，正確に決定する方法は無いといわざるを得 ない(多くの酸化物高温超层導体材料の場合).

$H_{\text {irr }}$ ：磁化曲線が不可逆になり始める磁界值(図 5 参照). 不可逆領域では, 磁界上昇時の磁化と下降時の磁化が 異なった値となり，両者の差 $\Delta M=\left|M_{\mathrm{up}}-M_{\text {down }}\right|$ が， その磁界下で超层導材料が持つ臨界電流密度 $J_{\mathrm{C}}$ 飞比 例する $\rho \equiv 0$ となるので, 小さな測定電流密度での $\rho(H)$ の測 定からも， $H_{\text {irr }}$ 決定できる.

†† 臨界電流密度 $J_{\mathrm{C}}$ の測定法の項を参照されたい。なお，低温超 伝導材料では, $H_{\mathrm{C} 2} \cong H_{\mathrm{irr}}$ であるため, $\rho(H)$ 測定の方法でも $H_{\mathrm{C} 2}$ が決定できる. 


\section{4. 臨界電流密度 $J_{\mathrm{C}}$ の測定法}

前項で述べた如く, $H_{\mathrm{irr}}$ 以下の磁界中では， $\rho \equiv 0$ である. この $\rho=0$ である最大の電流値を臨界電流 $I_{\mathrm{C}}$ という。 $I_{\mathrm{C}}$ を, その試料の断面積 $S$ で割れば, 臨界電流密度 $J_{\mathrm{C}}\left(=I_{\mathrm{C}} / S\right)$ が 得られる。したがって, 一定の磁界中で電流-電圧特性を測 定し, 電気抵抗(すなわち, 電圧) の現れ始めた電流値で $I_{\mathrm{C}}$ を定め， $J_{\mathrm{C}}=I_{\mathrm{C}} / S$ より， $J_{\mathrm{C}}$ を決定することができる.

Bean モデルによれば, 図 5 中で示した $\Delta M$ と $J_{\mathrm{C}}$ とは比 例関係にあり, $\Delta M=\mu_{0} J_{C} d(2 d:$ 試料厚さ) と表されるので, $M(H)$ の測定からも $J_{\mathrm{C}}$ が決定できる. 実際, 金属系低温超 厷導材料では, 良く一致した值が得られている。しかしなが ら, 酸化物高温超伝導体は, 層状の構造を持ち, 2 次元的な 強い異方性があり, 更に既に述べた如く, 巨大磁束流, 磁束 クリープ, ゆらぎ効果, 弱結合等々の影響が複雑に絡及合う ので，必ずしも等しい值が得られない，との報告が多い。 $J_{\mathrm{C}}$ は, 線材として実用する際の最る重要な特性であるので, そ の決定には, 実際に輸送電流を流して評価するトランスポー 卜法が良いと考兄られる。磁化測定から換算して得られた $J_{\mathrm{C}}$ 値は，参考值に留めるべきであると思われる。

最近, $\mathrm{Bi}$ 系酸化物の銀シーステープ線材を中心として, $30 \sim 40 \mathrm{~K}$ の中温域以下の温度でかなりの高 $J_{\mathrm{C}}$ が得られるよ 5 となり, 液体 $\mathrm{Ne}$ 中 $(\sim 27 \mathrm{~K})$ や小型冷凍機を用いての $J_{\mathrm{C}}(H)$ 測定が行わ机始めている. 特に東北大学金属材料研究 所の強磁場超伝導材料研究センターでは, $\mathrm{Y}$ 系の酸化物高 温超伝導体の電流リードを用いたクライオスタットをハイブ

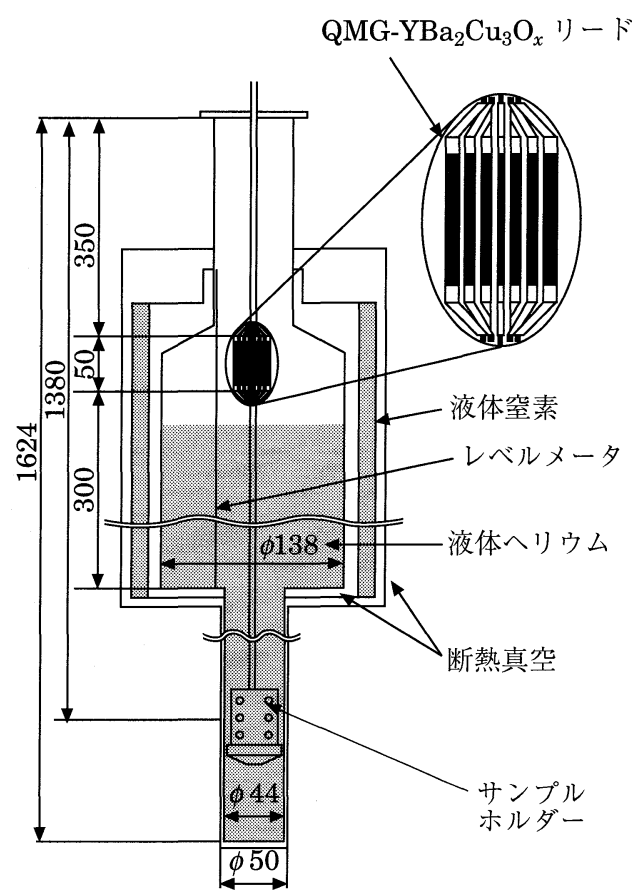

図 6 高磁界中での $J_{\mathrm{C}}$ 測定用クライオスタットの 1 例(3).
リッドマグネット中にセットして, 液体 $\mathrm{He}$ 温度で $27 \mathrm{~T}$ 迄 の高磁界中での $J_{\mathrm{C}}$ 測定が可能となっている( ${ }^{(3)}$. 図 6 亿その クライオスタットの概略図を示す.

(a)

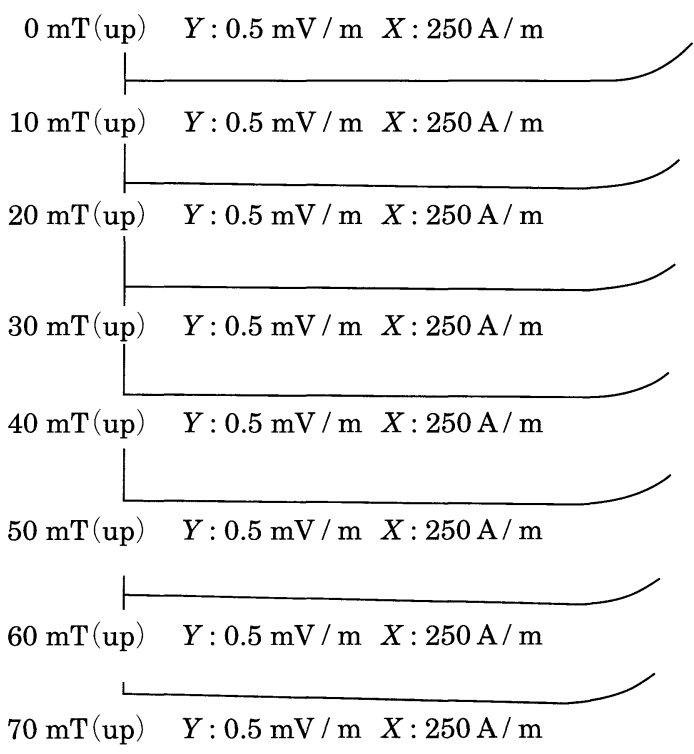

$80 \mathrm{mT}$ (up) $\quad Y: 0.5 \mathrm{mV} / \mathrm{m} X: 250 \mathrm{~A} / \mathrm{m}$

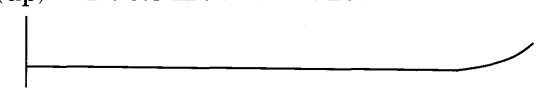

$90 \mathrm{mT}$ (up) $\quad Y: 0.5 \mathrm{mV} / \mathrm{m} \quad X: 250 \mathrm{~A} / \mathrm{m}$

$100 \mathrm{mT}(\mathrm{up}) \quad Y: 0.5 \mathrm{mV} / \mathrm{m} \quad X: 250 \mathrm{~A} / \mathrm{m}$

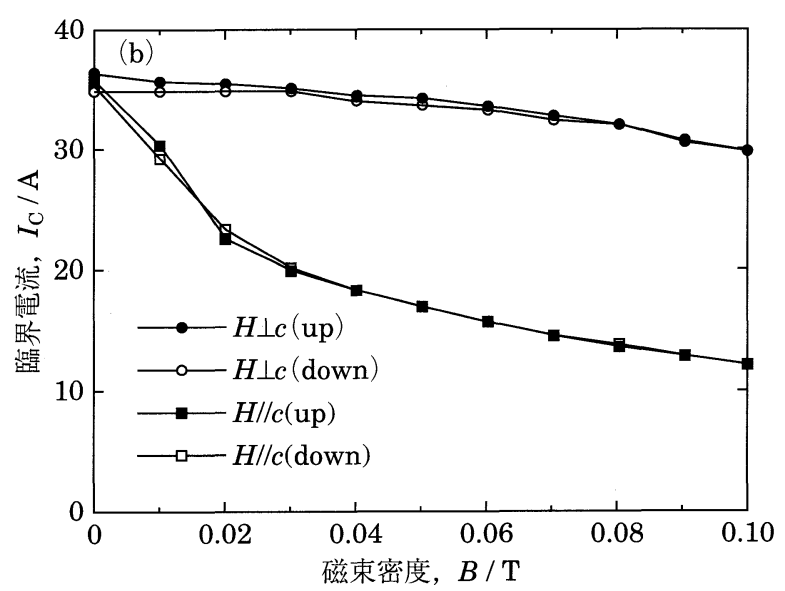

図 $7 J_{\mathrm{C}}(B)$ の 1 測定例. (a) は, V-I 曲線の XY レュー ダによる測定例で, $E=100 \mu \mathrm{V} / \mathrm{m}$ の電界基準で $I_{\mathrm{C}}$ を決定し， $J_{\mathrm{C}}=I_{\mathrm{C}} / S$ より $J_{\mathrm{C}}$ を求める. (b)は, このようにして求めた $J_{\mathrm{C}}$ の磁束密度依存性であ る. 磁束密度 : $B=\mu_{0} H$. 試料は $\mathrm{Bi}$ 系 (2223) 銀 シーステープ線材である。 
$I_{\mathrm{C}}$ の判定基準としては，100または $10 \mu \mathrm{V} / \mathrm{m}$ の電界基準 や $\left(10^{-11} \sim 10^{-13}\right) \Omega \cdot \mathrm{m}$ の抵抗率基準が用いられている.な お，トランスポート法による $J_{\mathrm{C}}$ 測定の際には， $T_{\mathrm{C}}$ の場合と 同様に正しい4 端子法によって行らことが肝要である。 た, 酸化物高温超伝導材料の多くは, 常伝導状態での電気抵 抗率 $\rho_{\mathrm{n}}$ が大きく, 熱伝導率が小さいため, 超伝導-常伝導転 移の際に, ジュール発熱で溶断したり，特性劣化を生じる場 合があるので，適当な保護抵抗を用いるかまたは転移直後に 電源を自動遮断して，ジュール発熱を防ぐことが必要であ る. 保護抵抗を用いる場合には電極部分での接続抵抗を極力 小さくし，かつ測定值に対する接続抵抗の補正が必要であ る. 更に, 転移の際の $n$ 值†は常にチェックしておくべきで

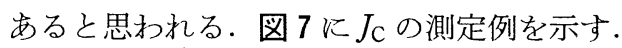

\section{5. 熱伝導率 $K(T, H)$ の測定}

熱伝導率は，超伝導状態に扮いても実測可能な輸送係数で ありキャリヤの性質や散乱機構を調べるのに有力な手段で ある. また工学的には, 線材として実用化する際の動的安定 性の評価や, 熱桩散率と組合せると比熱が算出できるので, 線材の磁気的不安定性の評価にも役立つ. 更に, 酸化物高温 超伝導材料を電流リードとして使用する際の熱侵入量の評価 に必要不可欠である. 図 8 亿, 我々が使用している熱伝導率 の温度依存性 $K(T)$ の測定装置の概略図を示す，小型冷凍機 のコールドヘッド上に試料をセットして，完全自動で約 15 $\mathrm{K}$ 室温までの熱伝導率が測定される ${ }^{(4)}$. この装置は，後に 述べる熱起電力も同時に測定できるし，熱拡散率も同一七ッ ティングで測定することができる。 また，磁界中熱伝導率 $K(H)$ は, 東北大学金属材料研究所の強磁場超伝導材料研究 センターの 15 T-SM 中に, 図 9 のよらなクライオスタット をセットして測定している(5). この装置は，一定温度での磁 界依存性のみならず, 一定磁界中での温度依存性も半自動で 測定が可能になっている。測定原理は定常熱流法で， $K=(L / S)(\dot{Q} / \Delta T), \dot{Q}:$ 与えた熱流 $[\mathrm{W}], \Delta T\left(=T_{2}-T_{1}\right):$ 生 じた温度勾配 $[\mathrm{K}], L:$ 温度計間距離 $[\mathrm{m}], S$ : 試料断面積 $\left[\mathrm{m}^{2}\right]$ で与えられる．測定にあたっての注意点は，(1)一様な熱流に なるよらに工夫すること，(2)温度計やヒーターのリード線を 伝って逃げる熱量を最小限に抑えること, (3)差動熱電対によ り， $\Delta T$ を直接測定すること，(4)熱シールドをとり付けるこ となどである. $K(T)$ の測定例を図10亿示す.酸化物高温超 伝導体の $K(T)$ は大変小さく, $I_{\mathrm{C}}$ まではジュール発熱なし に通電できるので, 超伝導マグネットの電流リードや大電力 用ブスバーとして最適であり，すでに実用の域に達してい る(6). 一方, 酸化物高温超伝導体の多くは図10にも見られ るよらなェンハンスメントを $T_{\mathrm{C}}$ 以下で示す。このエンハン

†超伝導-常伝導転移の際の電圧を $V \propto I^{n}$ と近似して，その指数 を $n$ 値といら. $n$ 値は, 線材の長尺均質性を反映すると考兄ら れている.

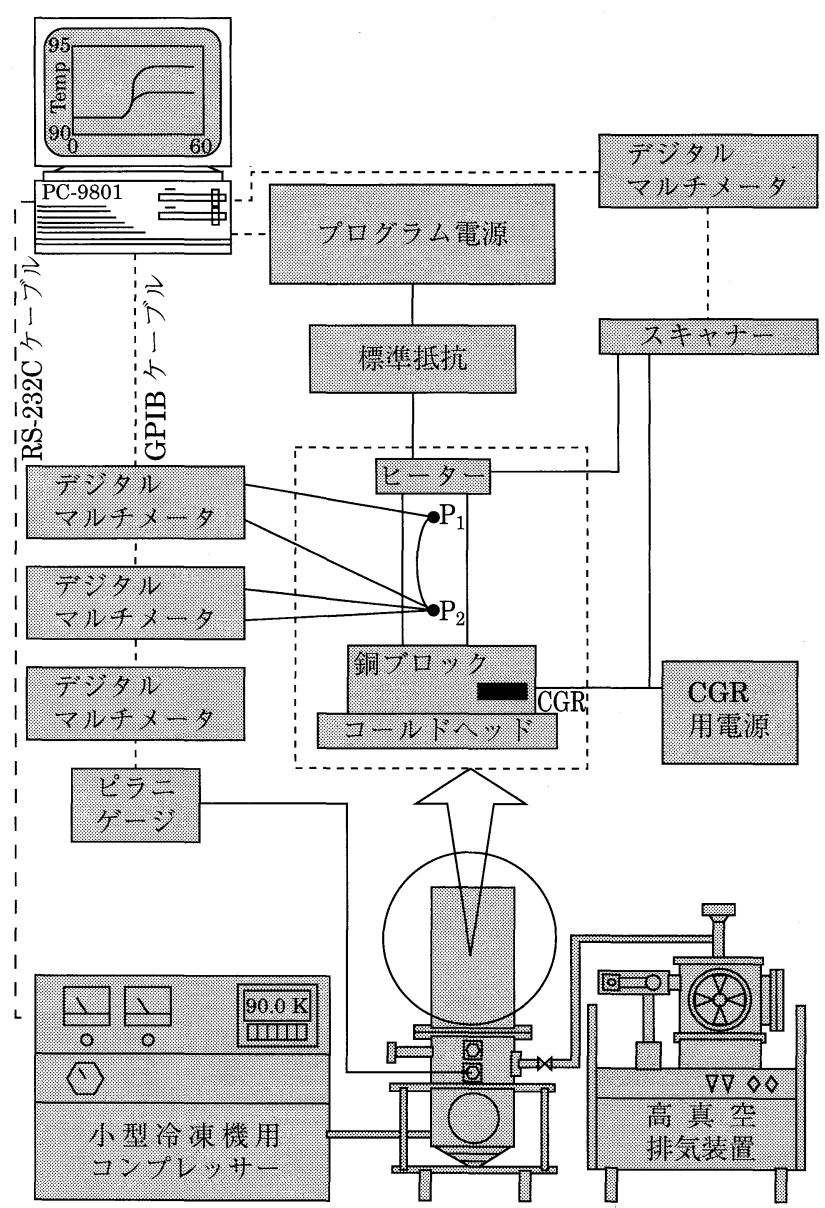

図 8 熱伝導率 $K(T)[T=$ 約 $15 \mathrm{~K}$ 室温 $]$ の完全自動 測定装置の概略図 ${ }^{(4)}$.

スメントの起因については, 現在フォノン説と電子説の 2 説があり，議論中でまだ解決していない。

\section{6. 熱拡散率 $\boldsymbol{D}(\boldsymbol{T})$ の測定}

熱拡散率の測定には通常, 熱フラッシュ法と呼ばれる方法 で測定されることが多い(7). これは, 板状の試料の片面にパ ルス状の熱を加え, 反対の面(裏面)にとり付けた温度計によ り，反対面まで熱が伝わる時間を測定して，熱拡散率 $D$ を 求めるものである。しかしながら我々は, 広い温度領域でか なりの精度を保ちつつ, 自動測定することをねらって, 図 8 に示した熱伝導率測定装置にセットしたままで(すなわら, 同一セッティングで), 温度プロフォイル法での測定を行っ ている(8)-(10). これは図 8 と同じセッティングのままでヒー ターによりパルス状の熱を加え, その後の $\mathrm{P}_{1}, \mathrm{P}_{2}$ 点での温 度の時間プロファイルを測定し， $\mathrm{P}_{1}$ 点での温度プロファイ ルを初期条件として一次元の熱伝導方程式 $\partial T(x, t) / \partial t=D$ $\partial^{2} T(x, t) / \partial x^{2}$ を解いた $\mathrm{P}_{2}$ 点での温度プロファイルを, $D$ を パラメーターとして最小二乗法フィッティングすることによ 


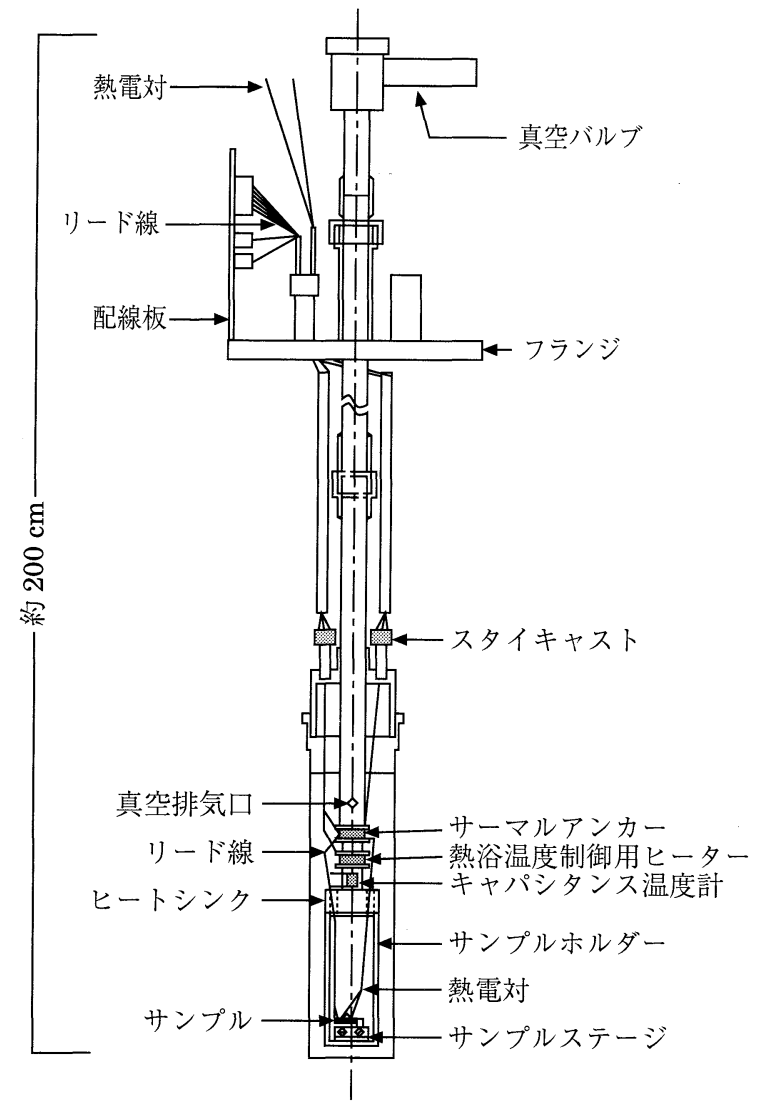

図 9 磁界中熱伝導率測定用クライオスタットの餗略 図 $^{(5)}$.

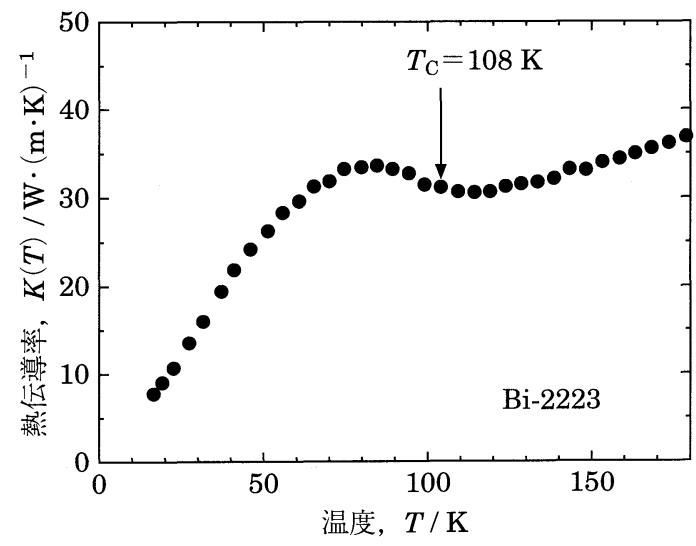

図10 Bi 系 (2223) 酸化物焼結体の熱伝導率 $K(T)$ 測定 例 ${ }^{(10)}$.
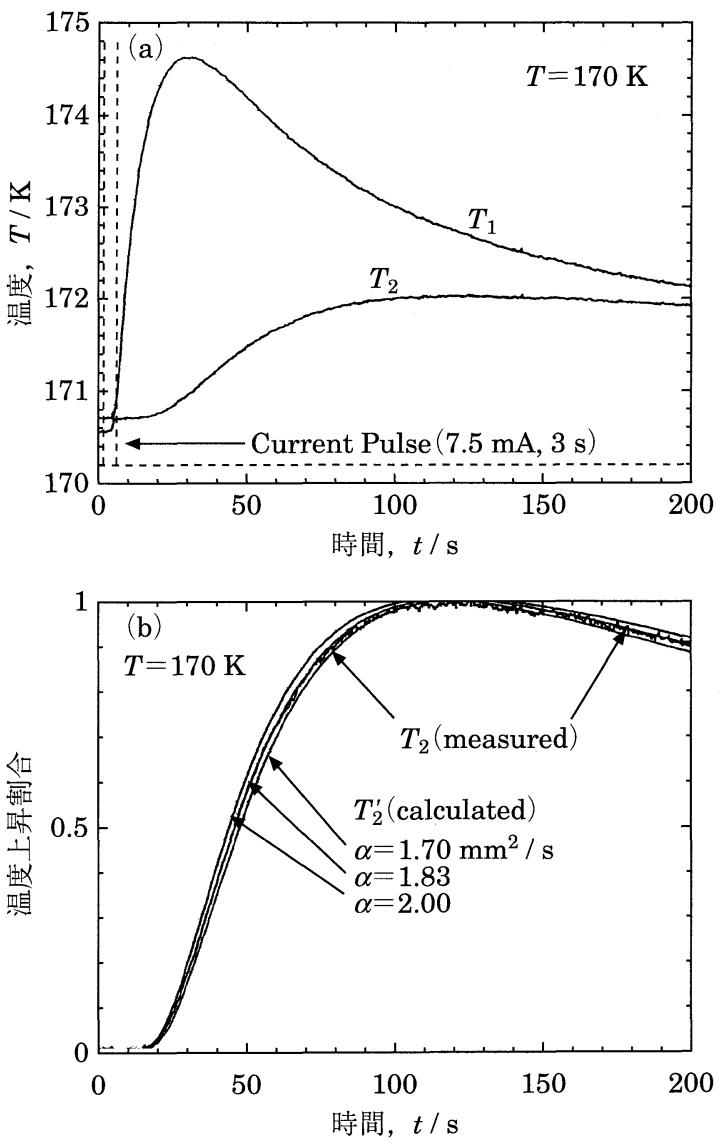

図11 熱拡散率測定のための温度プロファイル測定例.

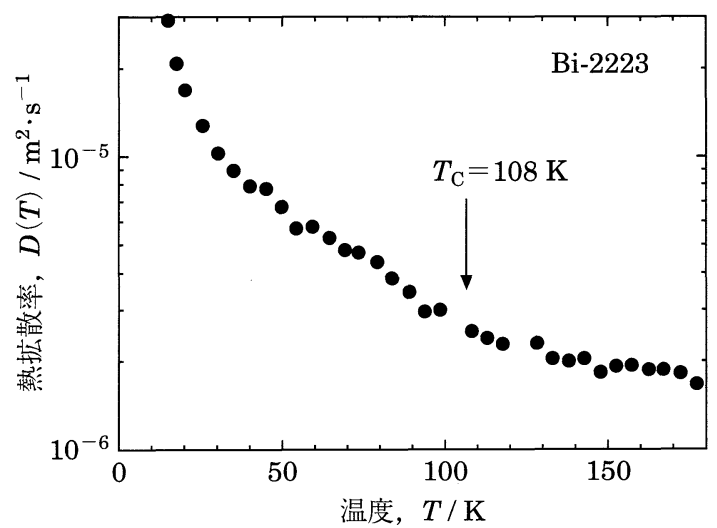

図12図10 同一試料の $D(T)$ 同一七ッティングに よる測定結果 ${ }^{(10)}$.

$T_{\mathrm{C}}$ での比熱のトビ $\Delta C$ などに対する詳細解析には, 不十分 といわざるを得ないが, 同一七ッティング測定のため, 絶対 值に対する確度はかなり高く, 工学的諸評価には十分利用で きると思われる。

\section{7. 熱起電力の測定}

我々のグループでは，熱起電力も， $K(T), D(T)$ 測定々 


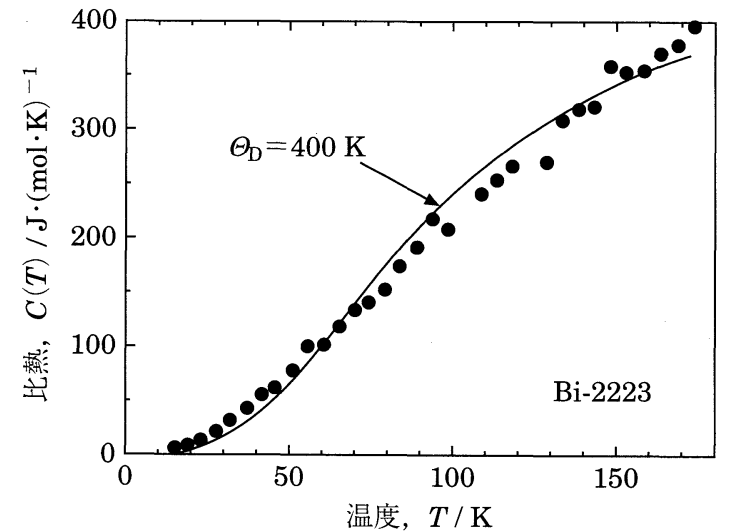

図13 $K(T)$ と $D(T)$ の同一七ッティング測定結果より 算出して求めた比熱 $C(T)$ の温度依存性 ${ }^{(10)}$. 実 線は,デバイモデルによりフィッティングした 曲線である。

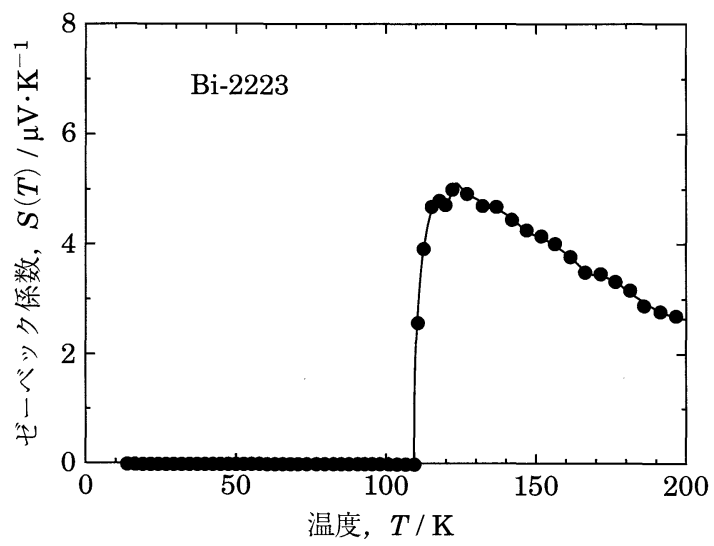

図14 Bi 系 (2223) 酸化物焼結体のゼーベック係数 $S(T)$ 測定例.

同じクライオスタットにより， $K(T)$ と同時測定が可能とな っている.ここで得られるのは, $\mathrm{Cu}$ との相対熱起電力であ り, $\mathrm{Cu}$ の絶対熱起電力を差し引いて, その試料の絶対熱起 電力が求められる. そして絶対熱起電力の温度に対する勾配 からゼーベック係数 $S(T)$ が得られる.このようにして求め た $S(T)$ の測定結果の 1 例を図14に示す.

この $S(T)$ から, キャリヤの判別(電子か? ホール か? )や電子構造に対する知見が得られるので, 注目される. また最近, 酸化物高温超伝導材料は, ペルチェ冷却素子とし ても注目されている(11). 超层導電子対は, エントロピーを 運ばないので, 超伝導体では $S \equiv 0$ となる. しかしながら， 熱伝導率が非常に小さいので, ペルチェ冷却の受動素子とし て使用し得る. 従来からの半導体によるペルチェ冷却では, $\mathrm{p}$ 形と $\mathrm{n}$ 形半導体を用いた $\pi$ 接合により冷却を行い，その 時のメリット係数 $Z$ は, $Z=S^{2} / \rho K$ (ただし $\rho$ は電気抵抗率) のように定義されている. しかし〜 $100 \mathrm{~K}$ 近傍以下の温度で は $\mathrm{p}$ 形半導体の $S$ が小さくなり, 冷却効果が臣とんど得ら れなくなる.そこで, $\mathrm{p}$ 形半導体の代わりに, 酸化物高温超 伝導体を用いたペルチェ冷却の研究が進められている(12) (13).

\section{8.むす ず}

超伝導の 3 つの臨界値である臨界温度, 臨界磁界, 臨界 電流密度および熱伝導率, 熱拡散率, 熱起電力(ゼーベック 係数)の測定法について, 主対象を酸化物高温超伝導材料に して，応用を目指す工学の立場より述べた。超伝導測定法と しては，交流損失，比熱，熱膨張率などの測定法も重要であ るが，紙面が限られていることもあり，割愛した，比熱の広 い温度領域での自動測定装置を, 我々は現在開発中である が，まだ完成していない，熱膨張率の研究は，ストレス効果 との関連で非常に重要である. 我々は最近, 差動トランスを 用いた簡便型(14)のものを開発したので, 興味ある方は参考 文献(14)を参照されたい. 交流損失の評価は現在, 酸化物 高温超伝導線材の開発研究の中心的課題であり, その測定法 そのものが議論されている段階である.

最後に，技官の藤沼重雄氏には，多くの実験の準備・補助 をして頂いて扣ります。本稿のワープロも同氏に物願い致し ました。深く感謝致します。

\section{文献}

(1) PHYSICS TODAY Mar. 1986 Special Issue "Superconductivity” (75th anniversary)和訳 : パリティ別冊, No. 1 (1986, 丸善)『超伝導』(75周年).

( 2 ) H. Takahashi, A. Tokiwa-Yamamoto, N. Mori, S. Adachi, H. Yamauchi and S. Tanaka: Physica C, 218(1993), 1.

( 3 ) K. Kimura, M. Sawamura, K. Miyamoto, M. Hashimoto, K. Watanabe, S. Awaji and N. Kobayashi: Adv. in Superconductivity, XII (1995), 851.

（4）保原夏朗, 松川倫明, 松浦伸悌, 藤代博之, 能登宏七: 低温 工学, 28(1993), 688. な牧, この装置は最近商品化され, 市 販されている. 吉澤秀二 : 低温工学, 30(1995), 519 .

( 5 ) 戸舘高広, 松川倫明, 能登宏七, 直原和哲, 石原 守, 山田 豊 : 低温工学, 30(1995), 495.

( 6 ) K. Watanabe, Y. Yamada, J. Sakuraba, F. Hata, C. K. Chong, T. Hasebe and M. Ishihara: Jpn. J. Appl. Phys., 32(1993), L488.

（７）熱物性ハンドブック, 日本熱物性学会編, 養賢堂.

（8）藤代博之, 池部學, 内藤智之, 能登宏七: 低温工学, 28(1993), 533.

（9）藤代博之, 内藤智之, 池部學, 能登宏七：低温工学, 28(1993), 582.

(10) M. Ikebe, H. Fujishiro, T. Naito and K. Noto: J. Phys. Soc. Jpn., 63(1994), 3107.

(11) A. B. Molosov and N. A. Sidorenko: Cryogenics 32, ICEC-14 Supplement, (1992), 36.

(12) H. Fujishiro, K. Kusaka, M. Ikebe, H. Ogasawara and K. Noto: Cryogenics, 34(1994), 231.

(13) T. Nakano and T. Hashimoto: Jpn. J. Appl. Phys., 33(1994), L1728.

(14) H. Ogasawara, M. Matsukawa, K. Noto and H. Kimura: Critical State in Superconductors Ed. K. Tachikawa, K. Kitazawa, H. Maeda and T. Matsushita, World Scientific, (1995), pp. 315-318.

H. Ogasawara, M. Matsukawa, K. Noto, H. Kimura and H. Tsukada: Physica B, 219 \& 220(1996), 166. 